\title{
OKLAHOMA GROUND-WATER QUALITY
}

\author{
By William F. Horak and Jerry D. Stoner
}

U.S. Geological Survey Open-File Report 87-0746 


\section{DEPARTMENT OF THE INTERIOR \\ DONALD PAUL HODEL, Secretary}

\section{U.S. GEOLOGICAL SURVEY \\ Dallas L. Peck, Director}

For additional information:

Chief Hydrologist

U.S. Geological Survey

407 National Center

Reston, VA 22092
For sale by:

U.S. Geological Survey

Books and Open-File Reports Section Federal Center

Box 25425

Denver, Colorado 80225

Use of trade names in this report is for descriptive purposes only and does not constitute endorsement by the U.S. Geological Survey 


\section{FOREWORD}

This report contains summary information on ground-water quality in one of the 50

States, Puerto Rico, the Virgin Islands, or the Trust Territories of the Pacific Islands, Saipan, Guam, and American Samoa. The material is extracted from the manuscript of the 1986 National Water Summary, and with the exception of the illustrations, which will be reproduced in multi-color in the 1986 National Water Summary, the format and content of this report is identical to the State ground-water-quality descriptions to be published in the 1986 National Water Summary. Release of this information before formal publication in the 1986 National Water Summary permits the earliest access by the public. 


\section{Contents}

Ground-Water Quality ................................ 1

Water-Quality in Principal Aquifers $\ldots \ldots \ldots \ldots \ldots \ldots \ldots \ldots \ldots \ldots \ldots \ldots \ldots \ldots \ldots \ldots$

Background Water Quality $\ldots \ldots \ldots \ldots \ldots \ldots \ldots \ldots \ldots \ldots \ldots \ldots \ldots \ldots$

Alluvial and Terrace Aquifers $\ldots \ldots \ldots \ldots \ldots \ldots \ldots \ldots \ldots \ldots \ldots \ldots$

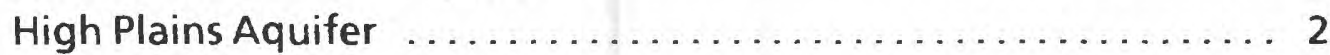

Rush Springs Aquifer ............................. 2

Dog Creek-Blaine Aquifer ......................... 2

Garber-Wellington Aquifer ........................ 2

Vamoosa-Ada Aquifer ............................ 2

Roubidoux Aquifer ............................. 2

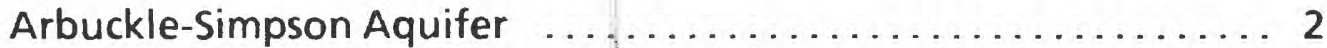

Arbuckle--Timbered Hills Aquifer $\ldots \ldots \ldots \ldots \ldots \ldots \ldots \ldots \ldots, 2$

Effects of Land Use on Water Quality $\ldots \ldots \ldots \ldots \ldots \ldots \ldots \ldots$

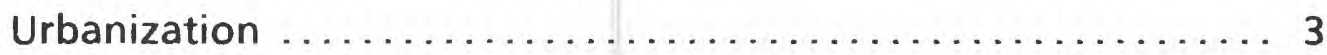

Agricultural Practices $\ldots \ldots \ldots \ldots \ldots \ldots \ldots \ldots \ldots \ldots \ldots \ldots \ldots \ldots$

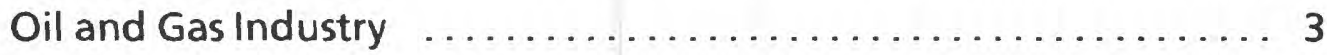

Waste Disposal ................................. 3

Potential for Water-Quality Changes $\ldots \ldots \ldots \ldots \ldots \ldots \ldots \ldots \ldots \ldots$

Ground-Water-Quality Management ...................... 4

Selected References ...................................... 5

Illustrations

Figure 1.--Selected geographic feature and 1985 population distribution in

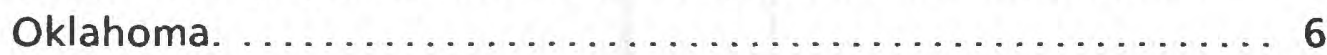

Figure 2.--Principal aquifers and related water-quality data in Oklahoma. ... 7

Figure 3.--Selected waste sites and ground-water quality information in

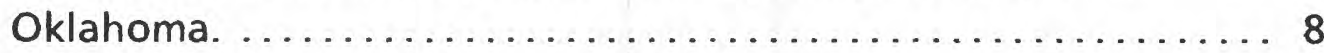

Figure 4.--Water types of the principal aquifers in Oklahoma. $\ldots \ldots \ldots \ldots .9$ 


\section{Oklahoma Ground-Water Quality}

In Oklahoma, ground water is the major source of water for irrigation, the largest single use of water. The major population centers (fig. 1) rely primarily on surface water for public supply, but many of the smaller towns and rural water systems depend on ground water. Ground water accounts for about 28 percent of the total public water supply in Oklahoma (Solley and others, 1983, p. 10). Except for the Dog Creek-Blaine and the Arbuckle-Timbered Hills aquifers (fig. $2 A$ ), the principal aquifers provide water supplies that generally meet all Federal and State standards for drinkingwater quality. Large sulfate concentrations, with a median value of $1,750 \mathrm{mg} / \mathrm{L}$ (milligrams per liter) in the Dog Creek-Blaine, and large fluoride concentrations, with a median value of $9.1 \mathrm{mg} / \mathrm{L}$ in the Arbuckle-Timbered Hills, preclude the general use of these two aquifers for public water supply. In all principal aquifers except the Arbuckle-Timbered Hills, the water is hard to very hard, with median hardness values ranging from 135 to $2,000 \mathrm{mg} / \mathrm{L}$ as calcium carbonate. All principal aquifers supply water of acceptable quality for irrigation of some types of crops.

Large nitrate (as nitrogen) concentrations are present in many of the State's aquifers, particularly in the shallow alluvium and terrace aquifers, but specific causes have not been identified. Evidence exists that ground water is contaminated in some areas by large sodium chloride concentrations resulting from oil and gas operations. Fifty hazardous-waste sites have been identified under the Federal Resource Conservation and Recovery Act (RCRA) of 1976 (fig. $3 A$ ). Of these 50 sites, ground-water-quality monitoring is required at 30 . Four sites in Oklahoma have been included on the National Priorities List (NPL) of hazardous waste sites (U.S. Environmental Protection Agency, 1986c) for action or further evaluation under the Comprehensive Environmental Response, Compensation, and Liability Act (CERCLA) of 1980. Remedial action is almost completed at the CERCLA (Superfund) site in northeastern Oklahoma (fig. $3 A$ ). There are 11 underground injection control (UIC) Class I wells (U.S. Environmental Protection Agency, 1984) in Oklahoma (fig. 3A). The U.S. Department of Defense (DOD) has identified 29 hazardous-waste sites at 4 facilities in Oklahoma as having potential for contamination.

Although the urban population has continued to increase, Oklahoma has had a net loss in population since 1983 (Oklahoma Employment Security Commission, 1986, p. 4) because of the depressed economy. Contamination of shallow ground water may occur in the urban areas as an indirect result of population and industrial growth. Statewide, the potential for ground-water contamination resulting from agriculture and energy production has been decreased by a reduction in these activities.

\section{WATER QUALITY IN PRINCIPAL AQUIFERS}

Oklahoma has three principal types of aquifers-alluvial, unconsolidated and semiconsolidated, and bedrock (U.S. Geological Survey, 1985, p. 347). Ground water in Oklahoma is withdrawn predominantly for irrigation and public supply, and is the source for most self-supplied domestic users. Irrigation is the primary water use in the western part of the State and public supply is the primary water use in the central and eastern parts. During 1982, groundwater withdrawals accounted for 46 percent of the total water withdrawals (Stoner, 1985, p. 18). Irrigation withdrawals from the High Plains, Rush Springs, and Dog Creek-Blaine aquifers in the west (fig. $2 A$ ) accounted for about 60 percent of the total State ground-water withdrawals.

Dissolved-solids concentrations in Oklahoma ground water generally increase with depth. Except for the Dog Creek-Blaine and the Arbuckle-Timbered Hills aquifers, water suitable for public supply can be found in all the State's principal aquifers. However, not all areas or depths within these aquifers produce water suitable for public supply.

\section{BACKGROUND WATER QUALITY}

A graphic summary of selected water-quality variables compiled from the U.S. Geological Survey's National Water Data Storage and Retrieval System (WATSTORE) is presented in figure $2 B$. The summary is based on dissolved-solids, hardness, fluoride, chloride, and sulfate analyses of water samples collected from 1946 to 1986 from the principal aquifers in Oklahoma. Percentiles of these variables are compared to national standards that specify the maximum concentration or level of a contaminant in drinking-water supply as established by the U.S. Environmental Protection Agency (1986 a,b). The primary maximum contaminant level standards are health related and are legally enforceable. The secondary maximum contaminant level standards apply to esthetic qualities and are recommended guidelines. The primary drinking-water standards include a maximum concentration of $4.0 \mathrm{mg} / \mathrm{L}$ fluoride, and the secondary drinking-water standards include maximum concentrations of 500 $\mathrm{mg} / \mathrm{L}$ dissolved solids, $2.0 \mathrm{mg} / \mathrm{L}$ fluoride, $250 \mathrm{mg} / \mathrm{L}$ chloride, and $250 \mathrm{mg} / \mathrm{L}$ sulfate.

The data presented in figure $2 B$ were summarized by principal aquifer and were interpreted for each aquifer without distinction as to areal location or depth. Owing to insufficient data, the Keokuk-Reeds Spring and Antlers aquifers have not been included in this discussion. Nitrate (as nitrogen) data were not sufficient to produce statistical summaries for any of the principal aquifers.

Except for the Dog Creek-Blaine aquifer, the median dissolved-solids concentrations in the State's principal aquifers were smaller than $1,000 \mathrm{mg} / \mathrm{L}$ and ranged from 280 to $772 \mathrm{mg} / \mathrm{L}$ (fig. $2 B$ ). Hardness concentrations for most of Oklahoma's ground water generally were larger than $120 \mathrm{mg} / \mathrm{L}$ (hard water) and commonly were larger than $180 \mathrm{mg} / \mathrm{L}$ (very hard water). Some chloride and sulfate concentrations exceeded the drinking-water standards of $250 \mathrm{mg} / \mathrm{L}$, rendering the water unsuitable for use as a public supply. Fluoride concentrations in water from some aquifers exceeded the $4.0 \mathrm{mg} / \mathrm{L}$ primary standard for the range in average annual temperature in Oklahoma of 58 to $64^{\circ} \mathrm{F}$ (Oklahoma Water Resources Board, 1984).

\section{Alluvial and Terrace Aquifers}

Water withdrawn from the alluvial and terrace aquifers is used principally for irrigation and domestic supply. Water from these aquifers ranged from a calcium-magnesium carbonatebicarbonate type to a calcium-magnesium sulfate type (U.S. Geological Survey, 1985, p. 348). The median dissolved-solids concentration was $485 \mathrm{mg} / \mathrm{L}$ (fig. $2 B$ ), with about 20 percent of the concentrations exceeding $1,000 \mathrm{mg} / \mathrm{L}$. The water was very hard, with a median hardness concentration of $340 \mathrm{mg} / \mathrm{L}$; more than 80 percent of the concentrations were larger than $180 \mathrm{mg} / \mathrm{L}$. Most of the chloride and sulfate concentrations were small; median values were $18 \mathrm{mg} / \mathrm{L}$ and $50 \mathrm{mg} / \mathrm{L}$, respectively. Fewer than 10 percent of the chloride concentrations and 20 percent of the sulfate concentrations exceeded $250 \mathrm{mg} / \mathrm{L}$. The median fluoride concentration was $0.3 \mathrm{mg} / \mathrm{L}$, and the maximum was $0.9 \mathrm{mg} / \mathrm{L}$. The water generally is suitable for use as a public supply. However, large chloride and sulfate concentrations found in some areas and at various depths decrease the suitability of the water for public supply. 


\section{High Plains Aquifer}

The major use of water from this aquifer is for irrigation. Public water suppliers in this area also rely on the High Plains aquifer for potable water. The water is a calcium-magnesium chloride-sulfate type (fig. 4). The median dissolved-solids concentration was $364 \mathrm{mg} / \mathrm{L}$ (fig. $2 B$ ), with about 10 percent of the samples exceeding $1,000 \mathrm{mg} / \mathrm{L}$. The water was very hard, with a median hardness concentration of $210 \mathrm{mg} / \mathrm{L} ; 95$ percent of the samples had concentrations larger than $180 \mathrm{mg} / \mathrm{L}$. The chloride and sulfate concentrations were small; median concentrations were $19 \mathrm{mg} / \mathrm{L}$ and $61 \mathrm{mg} / \mathrm{L}$, respectively. About 5 percent of the chloride and sulfate concentrations were larger than $250 \mathrm{mg} / \mathrm{L}$. The median fluoride concentration was $1.4 \mathrm{mg} / \mathrm{L}$, and about 25 percent of the concentrations exceeded $2.0 \mathrm{mg} / \mathrm{L}$. Although the water is suitable for use as a public supply, chloride, sulfate, and fluoride concentrations can be large enough to make the water unsuitable in some areas.

\section{Rush Springs Aquifer}

The primary use for water withdrawn from the Rush Springs aquifer is irrigation. The water is a calcium-magnesium chloridesulfate type (fig. 4). The median dissolved-solids concentration was $408 \mathrm{mg} / \mathrm{L}$ (fig. $2 B$ ), with about 25 percent of the concentrations greater than $1,000 \mathrm{mg} / \mathrm{L}$. The water was very hard, with a median hardness concentration of $270 \mathrm{mg} / \mathrm{L} ; 70$ percent of the concentrations were larger than $180 \mathrm{mg} / \mathrm{L}$. Chloride and sulfate concentrations were small; median values were $14 \mathrm{mg} / \mathrm{L}$ and $55 \mathrm{mg} / \mathrm{L}$, respectively. Fewer than 5 percent of the chloride concentrations and about 30 percent of the sulfate concentrations were larger than $250 \mathrm{mg} / \mathrm{L}$. The maximum fluoride concentration was $0.9 \mathrm{mg} / \mathrm{L}$. The water generally is suitable for public supply, although chloride and sulfate concentrations exceed the drinking-water standards in some areas.

\section{Dog Creek-Blaine Aquifer}

Water from the Dog Creek-Blaine aquifer is used almost exclusively for irrigation. The chemistry of the water, a calciummagnesium chloride-sulfate type (fig. 4), results from solution of the gypsum and dolomite in the aquifer. Water from this aquifer was slightly to moderately saline, with a median dissolved-solids concentration of $3,040 \mathrm{mg} / \mathrm{L}$ (fig. $2 B$ ). About 80 percent of the dissolved-solids concentrations were larger than $1,000 \mathrm{mg} / \mathrm{L}$. The water was very hard, with a median hardness concentration of 2,000 $\mathrm{mg} / \mathrm{L}$; more than 90 percent of the values were larger than 180 $\mathrm{mg} / \mathrm{L}$. The median chloride concentration was $145 \mathrm{mg} / \mathrm{L}$, and about 25 percent of the values exceeded $250 \mathrm{mg} / \mathrm{L}$. Sulfate concentrations were large; the median value was $1,750 \mathrm{mg} / \mathrm{L}$ and more than 75 percent of the concentrations were larger than $250 \mathrm{mg} / \mathrm{L}$. The maximum fluoride concentration was $0.7 \mathrm{mg} / \mathrm{L}$. The water is unsuitable for use as a public-water supply.

\section{Garber-Wellington Aquifer}

The primary use for water withdrawn from the GarberWellington aquifer is for public supply and self-supplied domestic use. The water is a calcium-magnesium carbonate-bicarbonate type (fig. 4). The median dissolved-solids concentration was $372 \mathrm{mg} / \mathrm{L}$ (fig. $2 B$ ), with about 10 percent of the concentrations larger than $1,000 \mathrm{mg} / \mathrm{L}$. The water was hard to very hard, with a median hardness concentration of $190 \mathrm{mg} / \mathrm{L}$; more than 75 percent of the values were larger than $120 \mathrm{mg} / \mathrm{L}$. Chloride and sulfate concentrations normally were small; median concentrations were 17 and $18 \mathrm{mg} / \mathrm{L}$, respectively. About 10 percent of the chloride and 10 percent of the sulfate concentrations were larger than $250 \mathrm{mg} / \mathrm{L}$. The median fluoride concentration was $0.1 \mathrm{mg} / \mathrm{L}$, and fewer than 10 percent of the values were larger than $2.0 \mathrm{mg} / \mathrm{L}$. The water in the aquifer normally is suitable for use as a potable water supply, but chloride, sulfate, and fluoride concentrations may exceed the drinking-water standards.

\section{Vamoosa-Ada Aquifer}

Water withdrawn from the relatively undeveloped VamoosaAda aquifer is used primarily for drinking. The water is a sodiumpotassium chloride-sulfate type (fig. 4), with a tendency toward a sodium-potassium mixed type. The median dissolved-solids concentration was $325 \mathrm{mg} / \mathrm{L}$ (fig. $2 B$ ), with 10 percent of the concentrations greater than $1,000 \mathrm{mg} / \mathrm{L}$. The water ranged from soft to very hard, with a median hardness concentration of $135 \mathrm{mg} / \mathrm{L}$; about 45 percent of the values were larger than $180 \mathrm{mg} / \mathrm{L}$. Chloride and sulfate concentrations generally were small; median concentrations were 20 and $23 \mathrm{mg} / \mathrm{L}$, respectively. About 10 percent of the chloride and 1 percent of the sulfate concentrations were larger than 250 $\mathrm{mg} / \mathrm{L}$. The maximum fluoride concentration was $1.3 \mathrm{mg} / \mathrm{L}$. Except for areas of local contamination resulting from past oil and gas activities, the water is suitable for use as a public supply.

\section{Roubidoux Aquifer}

Water from the Roubidoux aquifer is withdrawn primarily for public-supply use, and the aquifer is the principal source of potable water for Ottawa County. The water is a mixed type with a tendency toward a sodium-potassium chloride-sulfate type (fig. 4). The median dissolved-solids concentration was $280 \mathrm{mg} / \mathrm{L}$ (fig. $2 B$ ), with about 5 percent of the concentrations larger than $1,000 \mathrm{mg} / \mathrm{L}$. The water was hard, with a median hardness concentration of $140 \mathrm{mg} / \mathrm{L}$; about 80 percent of the values were larger than $120 \mathrm{mg} / \mathrm{L}$. Chloride and sulfate concentrations generally were small; median concentrations were 50 and $15 \mathrm{mg} / \mathrm{L}$, respectively. About 15 percent of the chloride concentrations and 1 percent of the sulfate concentrations were larger than $250 \mathrm{mg} / \mathrm{L}$. The median fluoride concentration was $0.7 \mathrm{mg} / \mathrm{L}$; about 15 percent of the values were larger than $2.0 \mathrm{mg} / \mathrm{L}$. The water normally is suitable for use as a public supply, although chloride, sulfate, and flouride concentrations exceeded the drinking-water standards in some areas.

\section{Arbuckle-Simpson Aquifer}

The Arbuckle-Simpson aquifer is used primarily for drinking water, but the aquifer is largely undeveloped. The water is a calcium-magnesium carbonate-bicarbonate type (fig. 4). The median dissolved-solids concentration was $369 \mathrm{mg} / \mathrm{L}$ (fig. $2 B$ ), with about 10 percent of the concentrations greater than $1,000 \mathrm{mg} / \mathrm{L}$. The water was very hard, with a median hardness concentration of $330 \mathrm{mg} / \mathrm{L}$; all hardness concentrations were larger than $180 \mathrm{mg} / \mathrm{L}$. Chloride and sulfate concentrations were small; median concentrations were 21 and $18 \mathrm{mg} / \mathrm{L}$, respectively. About 25 percent of the chloride and 10 percent of the sulfate concentrations were larger than $250 \mathrm{mg} / \mathrm{L}$. The median fluoride concentration was $0.2 \mathrm{mg} / \mathrm{L}$, with about 30 percent of the values larger than $2.0 \mathrm{mg} / \mathrm{L}$. Much of the water in the aquifer is potable, but large concentrations of chloride and fluoride in some areas may make the water unsuitable for public supply.

\section{Arbuckle-Timbered Hills Aquifer}

The Arbuckle-Timbered Hills aquifer is largely undeveloped, but some water is withdrawn for domestic and irrigation use. The water is a sodium-potassium mixed type (fig. 4). The median dissolved-solids concentration was $772 \mathrm{mg} / \mathrm{L}$ (fig. $2 B$ ), with about 35 percent of the concentrations larger than $1,000 \mathrm{mg} / \mathrm{L}$. The water was soft, with a median hardness concentration of $21 \mathrm{mg} / \mathrm{L}$. Chloride concentrations generally were large, with a median concentration of $190 \mathrm{mg} / \mathrm{L}$; about 40 percent of the chloride concentrations exceeded $250 \mathrm{mg} / \mathrm{L}$. The median sulfate concentration was $70 \mathrm{mg} / \mathrm{L}$, and about 25 percent of the values exceeded $250 \mathrm{mg} / \mathrm{L}$. Fluoride concentrations were very large, with a median concentration of $9.1 \mathrm{mg} / \mathrm{L}$; about 75 percent of the concentrations were larger than $2.0 \mathrm{mg} / \mathrm{L}$. The water normally is unsuitable for public 
supply because of the widespread occurrence of large chloride and fluoride concentrations.

\section{EFFECTS OF LAND USE ON WATER QUALITY}

Changes in the quality of Oklahoma's ground water generally have not been documented by repeated sampling of specific wells. Poor ground-water quality may represent human-induced degradation or, more commonly in Oklahoma, impairment may be natural. With the limited information available, it is usually difficult to distinguish whether water-quality impairment is natural or human induced. Analyses for the class of contaminants that nearly always are attributable to human activities, such as organic compounds, are almost totally lacking for Oklahoma ground water.

Of the 11 major Oklahoma aquifers (fig. $2 A$ ), the Roubidoux is the only aquifer for which appreciable trace-metals data are available. Of the trace metals, cadmium exceeded the maximum contaminant level of $10 \mu \mathrm{g} / \mathrm{L}$ (micrograms per liter) (U.S. Environmental Protection Agency, 1986a) in 4 of 91 samples taken from the Roubidoux. Eleven of the 26 samples from the Roubidoux that were analyzed for gross alpha activity exceeded the maximum contaminant level of 15 picocuries per liter. Of the constituents covered by the drinking-water standards, chloride and sulfate most commonly exceeded the $250-\mathrm{mg} / \mathrm{L}$ limits. Sulfate concentrations in more than 75 percent of the samples from the Dog Creek-Blaine aquifer exceeded $250 \mathrm{mg} / \mathrm{L}$; for this reason the aquifer is represented as naturally impaired in figure $3 B$. The ArbuckleTimbered Hills aquifer also is shown in figure $3 B$ as naturally impaired, owing to the persistence of fluoride concentrations in excess of the drinking-water standard.

Many occurrences of substandard ground-water quality may not be attributed with confidence to specific causes or factors. Although available nitrate data were insufficient to produce statistics (fig. $2 B$ ), nitrate contamination commonly is measured in Oklahoma's ground water. Most of the nitrate data are stored in the files of various State agencies. Samples from one or more wells in virtually every major aquifer in the State have nitrate concentrations that exceed the $10-\mathrm{mg} / \mathrm{L}$ maximum contaminant level. The alluvial and terrace aquifers, because they tend to have shallow water tables and overlying soils with large permeability values, are particularly susceptible to nitrate contamination resulting from fertilizer application, septic-tank effluent, and industrial-process wastes. In addition, the outcrop areas of bedrock aquifers are susceptible to the same contaminants. Seventeen of the wells that yield contaminated water shown in figure $3 B$ are public-supply wells with nitrate problems. The actual number of affected wells, both public and private, is larger, but accurate locations for the wells were not available. Gopal (1984) reported on an area in western Woodward County (fig. $3 B$ ) where nitrate concentrations exceeded $10 \mathrm{mg} / \mathrm{L}$ in at least one of several repetitive samples in 40 percent of the shallow wells tested. The contamination was attributed to various sources at specific sites.

\section{Urbanization}

The effects of urbanization on ground-water quality in Oklahoma are not well documented. The State's largest city, Oklahoma City, overlies the Garber-Wellington aquifer, which is a principal water-supply source for parts of the metropolitan area. Most of the available chemical data for the Garber-Wellington are from municipal wells completed in the deeper parts of the aquifer. Nitrate contamination is a common problem in the shallow areas of the aquifer. Data are lacking to determine if trace metals and organic compounds are present in the shallow zones of the aquifer that would be affected first by human activities. Arsenic, chromium, and selenium in excess of the drinking-water standards are common, but the source of these dissolved metals is presumed to be minerals that occur naturally in the aquifer.

\section{Agricultural Practices}

The major known effect of agriculture on ground-water quality in Oklahoma is nitrate contamination. Chemigation is practiced in several areas of Oklahoma, but ground-water contamination resulting from a system malfunction, accident, or misuse of the practice has not been documented. Also, there is no evidence that pesticides are present in Oklahoma's ground water. However, very few analyses for pesticides have been made as of March 1986. The Oklahoma State Department of Agriculture began a project in 1986 to sample for pesticides in shallow aquifers throughout Oklahoma. This project is the first systematic effort to look statewide for evidence of pesticides in ground water.

\section{Oil and Gas Industry}

One of the ground-water-quality issues of great concern in Oklahoma is the contamination potential of oil and gas exploration and production. Nearly 400,000 oil and gas wells have been drilled in Oklahoma since oil was first produced in 1891 (Northcutt, 1985). Until several years ago, the requirements for plugging abandoned wells were not stringent regarding the protection of freshwater aquifers. Many of the older unplugged or partly plugged wells may serve as conduits for saltwater movement from deep reservoirs into shallower freshwater aquifers. Leaking casings in old producing wells or saltwater-injection wells could have a similar effect. Imperfectly sealed drilling-fluid disposal pits and brine-evaporation pits also may contribute contaminants to ground water. The contaminants typically associated with oil and gas activity are chloride. chromium, and sodium. Other trace metals that are a part of the natural composition of the brines produced with the oil and gas. and metals that are used in drilling-fluid additives also may be introduced to freshwater zones.

Two published reports are known to relate activities of the oil and gas industry directly to demonstrated ground-water contamination. An investigation into the cause of apparent saltwater contamination of the Vamoosa-Ada aquifer and overlying streams in central Oklahoma indicated that the quality of ground water in the vicinity of 15 wells (fig. $3 B$ ) had been degraded by oilfield brines (Morton, 1984). Leakage from evaporation pits was the presumed cause of large chloride concentrations, as much as $9,000 \mathrm{mg} / \mathrm{L}$, discovered in an area of several square miles in the southern part of the Cimarron Terrace aquifer in Logan County (fig. $3 B$ ) (Oklahoma Water Resources Board, 1975).

\section{Waste Disposal}

Early in 1986, State records showed that Oklahoma had 106 active municipal landfills (fig. $3 C$ ), and 50 RCRA sites for storage or disposal of hazardous waste, 4 CERCLA sites, and 11 UiC wells (fig. $3 A$ ). About 30 of the RCRA sites have permits for land disposal and must have ground-water monitoring networks in place. Groundwater contamination has not been detected at any of the RCRA sites; however, many do not yet (1986) have monitoring networks fully in place. Contamination has been documented at one of the CERCLA sites. There are two commercial waste-disposal facilities in Oklahoma. One, a land-disposal facility, is in Major County. The other facility (two disposal wells) is in Tulsa County. Both facilities also are RCRA sites.

As of September 1985, 29 hazardous-waste sites at 4 facilities in Oklahoma had been identified by the DOD as part of their Installation Restoration Program (IRP) as having potential for contamination (U.S. Department of Defense, 1986). The IRP. established in 1976, parallels the U.S. Environmental Protection Agency (EPA) Superfund program under CERCLA. The EPA presently ranks these sites under a hazard ranking system and may include them in the NPL. Of the 29 sites in the program, 3 sites contained contaminants but did not present a hazard to the environment. Three other sites, all at one facility (fig. $3 A$ ), were considered to present 
a hazard significant enough to warrant response action in accordance with CERCLA. The remaining sites are scheduled for confirmation studies to determine if remedial action is required.

One of Oklahoma's CERCLA sites, the Tar Creek site in Ottawa County (fig. $3 A$ ), has posed a threat to ground-water quality in the Roudidoux aquifer, a major source of water for public supply in northeastern Oklahoma. Abandoned underground lead-zinc mines have filled with water and large concentrations of iron, zinc, and sulfate now are evident in the mine water. Other constituents present in lesser, but significant, concentrations include aluminum. arsenic. cadmium, cobalt, lead, manganese, and nickel. The mines are located in the Boone Formation. Hydraulic gradients in the area indicate that mine water will migrate laterally within the formation and may migrate downward into other formations, including the Roubidoux aquifer. Many abandoned wells, which once supplied water for mining and milling operations, penetrate the Roubidoux aquifer and now provide a conduit for the mine water to reach the Roubidoux aquifer. A major goal of a CERCLA remedial project that will conclude in 1986 is to plug all abandoned wells in the area that could convey water from the mine workings to the Roubidoux aquifer.

Feasibility studies at the CERCLA site in southern McClain County (fig. $3 A$ ), the Hardage/Criner site, have been completed. and the proposed cleanup plans were issued for public comment early in 1986. The U.S. Department of Justice filed a civil suit in June 1986 against 36 companies to arrange for and to pay for cleanup of the 60 -acre site. From 1972 through 1980 the site was operated as an industrial waste-disposal facility, and more than 18 million gallons of liquid waste were accepted. The wastes include polychlorinated biphenyls, cyanides, solvents, acids, caustics, oil, paints, plating and etching solutions, waste ink, carbon black. pesticides, and sludges containing trace metals (U.S. Environmental Protection Agency, 1986d). Additional investigation at this site is planned to determine the extent, if any, of ground-water contamination.

As of June 1986, cleanup of the Sand Springs Petrochemical Complex near Tulsa (fig. 3A) was underway. Federal and State response actions were underway at the Compass Industries site, also near Tulsa, but cleanup activities had not begun (U.S. Environmental Protection Agency, 1986c).

A hydrogeologic investigation was begun in 1985 to determine if ground-water contamination had occurred near several former waste-disposal sites on Tinker Air Force Base in the Oklahoma City metropolitan area. A preliminary investigation indicates that trichloroethylene (TCE) is present in the GarberWellington aquifer in a localized area beneath one of the disposal sites (U.S. Army Corps of Engineers, Tulsa District, oral commun., 1986).

\section{POTENTIAL FOR WATER-QUALITY CHANGES}

The two major land-use activities in Oklahoma, agriculture and energy production, are likely to decrease. To improve its economy, Oklahoma is seeking to diversify its economic base and lessen its dependence on agriculture and energy production. The potential for change in ground-water quality by this diversification will depend to a great extent on the types of industry that are attracted.

Reduction in agricultural activity, particularly in crop production, could decrease potential ground-water contamination. A decrease in crop production would reduce the application of fertilizer and pesticides, as well as reduce the amount of irrigation water applied to the land surface. The potential for increased nitrate contamination of ground water from agricultural activities probably will not increase soon. However, if crop production in Oklahoma increases, it could increase the potential for change in water quality.
Oil and gas exploration and production presently (1986) are curtailed in Oklahoma because of unfavorable market conditions. Pumping from many marginal production wells has ceased because of the economic unfeasibility of continued operation. The potential for acceleration of changes in ground-water quality due to energy production or exploration will be minimal while the current market conditions exist. The potential for water-quality changes from past oil and gas operations probably will not change appreciably.

\section{GROUND-WATER-QUALITY MANAGEMENT}

Seven Oklahoma State agencies share statutory authority for the management and protection of ground-water quality. The Oklahoma Department of Pollution Control, one of the seven agencies, has the primary duty of coordinating the activities of other State agencies relating to environmental pollution when duplication of effort is possible. The Department functions as a clearing house for pollution complaints, particularly if there is a jurisdictional question. The Department is administered by a board composed of the heads of seven other agencies (one of which has no ground-water management authority) with responsibilities relating to the prevention and control of water pollution.

The Oklahoma Water Resources Board is responsible for the allocation of water rights that are based on hydrologic investigations of the State's aquifers, including considerations of possible ground-water pollution. The board is authorized to classify the State's water according to beneficial uses and to promulgate waterquality standards to protect those uses. The board also establishes well-construction standards, primarily to protect ground-water quality.

The Oklahoma State Department of Health has broad authority stemming from its mandate to safeguard the health of the State's people. It has jurisdiction in any situation that could contaminate or has contaminated a drinking-water source. The Department has approval and regulatory authority for all public water supplies, solid waste-management facilities, and septic systems. It also regulates hazardous waste, including the RCRA sites, and all classes of UIC wells except Class II.

The Oklahoma Corporation Commission has sole jurisdiction over any production activities of the oil and gas industry that may affect ground water. It has the authority to issue rules and regulations to prevent pollution of ground water that may result from those activities. The Commission administers that part of the UIC program that deals with saltwater-disposal wells and enhancedrecovery injection wells (Class II wells). It also is responsible for inventories in Oklahoma that are required by the Underground Storage Tank program of the EPA (RCRA of 1976).

The Oklahoma State Department of Agriculture has jurisdiction over the labeling, sale, handling, and use of pesticides and herbicides. Statutory authority gives the Department some control over the eventual distribution of applied pesticides in the environment. The Department also regulates feedlots and may promulgate rules to prevent contamination of natural waters.

The Oklahoma Conservation Commission has jurisdiction over nonpoint-source pollution programs that are not specifically delegated to other authorities, but its enforcement role is limited. The Oklahoma Department of Mines is responsible for approval of mine permits and regulation of mining operations to assure minimal disturbance to the quantity and quality of water resources.

The Oklahoma Department of Pollution Control coordinates the efforts of several agencies to develop an integrated strategy for the protection of Oklahoma's ground water. An important interim result of that work has been the recognition that many of the waterquality data that are needed to implement an effective protection strategy - one that includes enforceable water-quality standardscurrently are not available. A ground-water-quality monitoring pro- 
gram begun in 1983 by the Oklahoma Water Resources Board has provided trace-metals data for areas where previously there were none, but analyses for organic compounds are few.

\section{SELECTED REFERENCES}

Gopal. B.K., 1984. Ground-water prototype project-Nitrate contanination in ground water: Oklahoma Water Resources Board. 208 Work Task $861,119 \mathrm{p}$.

Marcher. M.V.. 1972, Major sources of water in Oklahoma, in K.S. Johnson and others, Geology and earth resources of Oklahoma, an atlas of maps and cross sections: Oklahoma Geological Survey Educational Publication I. p. 8

Morton. R.B.. 1984, Effects of brine on the chemical quality of water in parts of Creek, Lincoln, Okfuskee, Payne, Pottawatomie, and Seminole Counties. Oklahoma: U.S. Geological Survey Open-File Report 84-445. $66 \mathrm{p}$

Northcutt, R.A., 1985, Oil and gas development in Oklahoma. 1891-1984: Shale Shaker. June-July 1985.

Oklahoma Employment Security Comnission, 1986. Population estimates April 1, 1980, to July 1. 1985: Oklahoma Employnent Security Commission, $34 \mathrm{p}$.

Oklahoma Water Resources Board. 1975. Salt water detection in the Cimarron Terrace, Oklahoma: National Environmental Research Center. Office of Research and Development, U.S. Environmental Protection Agency, EPA-660/4-74-033. 166 p.

1984, Oklahoma's water atlas: Oklahoma Water Resources Board Publication No. 120, 156 p.

Solley. W.B.. Chase. E.B., and Mann. W.B., IV. 1983, Estimated use of water in the United States in 1980: U.S. Geological Survey Circular $1001,56 \mathrm{p}$.
Stoner, J.D., 1985, Reported withdrawals and estimated use of water in Oklahoma during 1982: U.S. Geological Survey Water-Resources Investigations Report 85-4084. 96 p.

U.S. Department of Defense. 1986. Status of the Department of Defense Installation Restoration Program-Information paper: Washington, D.C.. U.S. Department of Defense. Office of the Assistant Secretary of Defense (Acquisition and Logistics). Environmental Policy Directorate. February, $35 \mathrm{p}$.

U.S. Environmental Protection Agency, 1984. Classification of injection wells (section 146.5 of subpart A of part 146. Underground injection control program: criteria and standards): U.S. Code of Federal Regulations. Title 40, Part 146. July I, 1984, p. 371-372.

1986a, Maximum contaminant levels (subpart B of part 141, national interim primary drinking-water regulations): U.S. Code of Federal Regulations. Title 40. Parts 100 to 149, revised as of July I, 1986. p. $524-528$.

1986b. Secondary maximum contaminant levels (section 143.3 of part 143, national secondary drinking-water regulations): U.S. Code of Federal Regulations. Title 40, Parts 100 to 149, revised as of July I. 1986. p. $587-590$.

1986c. Amendment to National Oil and Hazardous Substances Contingency Plan; national priorities list, final rule and proposed rule: Federal Register, v. 51, no. 111, June 10, 1986, p. 21053-21112. 1986d. EPA environmental news: Press release dated June 25. 1986. issued by U.S. Environmental Protection Agency, Region IV, Dallas. Texas.

U.S. Geological Survey, 1985, National water summary 1984-Hydrologic events, selected water-quality trends, and ground-water resources: U.S. Geological Survey Water-Supply Paper 2275, 467 p.

Prepared by W. F. Horak and Jerry D. Stoner 


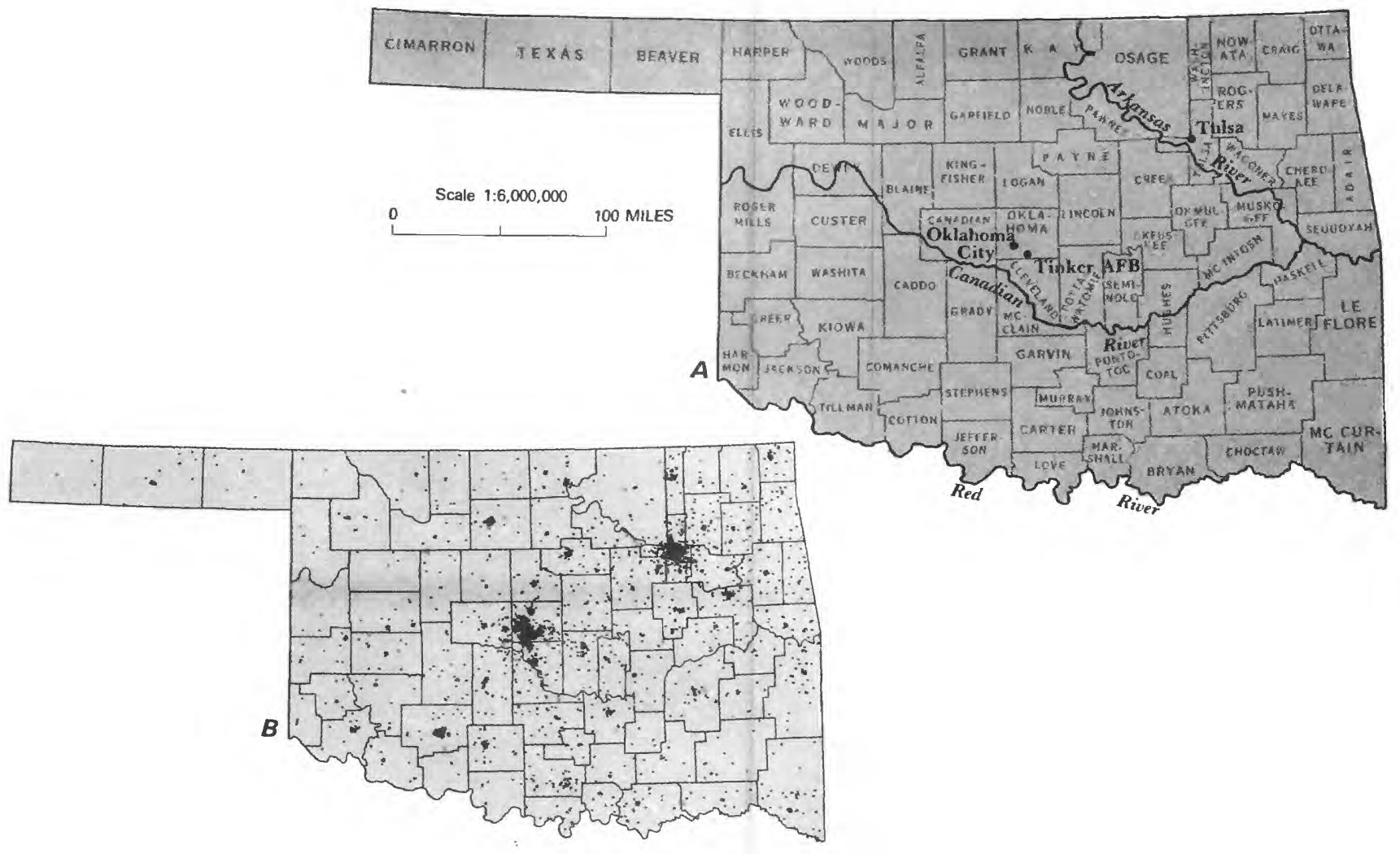

Figure 1. Selected geographic features and 1985 population distribution in Oklahoma. $A$, Counties, selected cities, and major drainages. $B$, Population distribution, 1985; each dot on the map represents 1,000 people. (Source: B. Data from U.S. Bureau of the Census 1980 decennial census files, adjusted to the 1985 U.S. Bureau of the Census data for county populations.) 

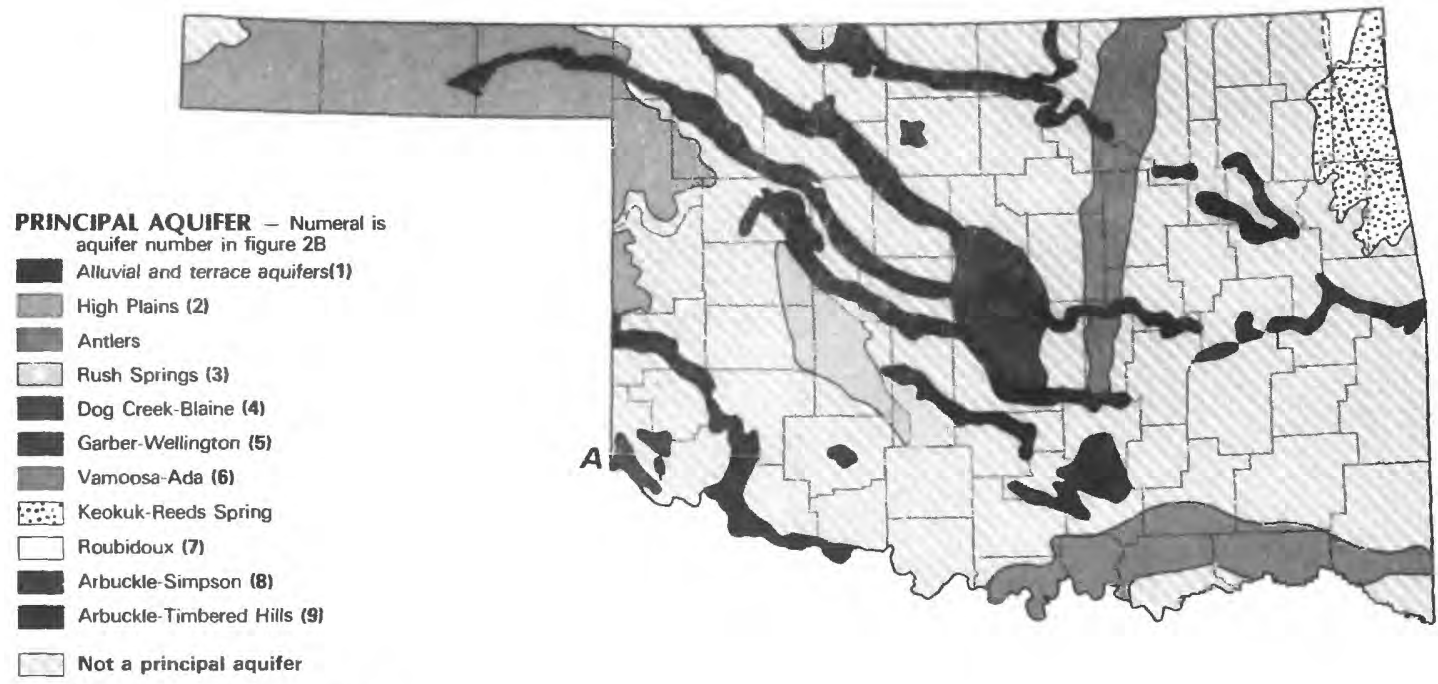

-.... Boundary of aquifer uncertain

\section{B WATER-QUALITY DATA}

Percentile Percentage of analyses equal
to or less than indicated values
90 th
-75 th
-50 th
-25 th
-10 th
National drinking-water standards
Maximum permissible contaminant
level (primary)
- Maximum recommended contaminant
level (secondary)
Reporting limit
analytical method used
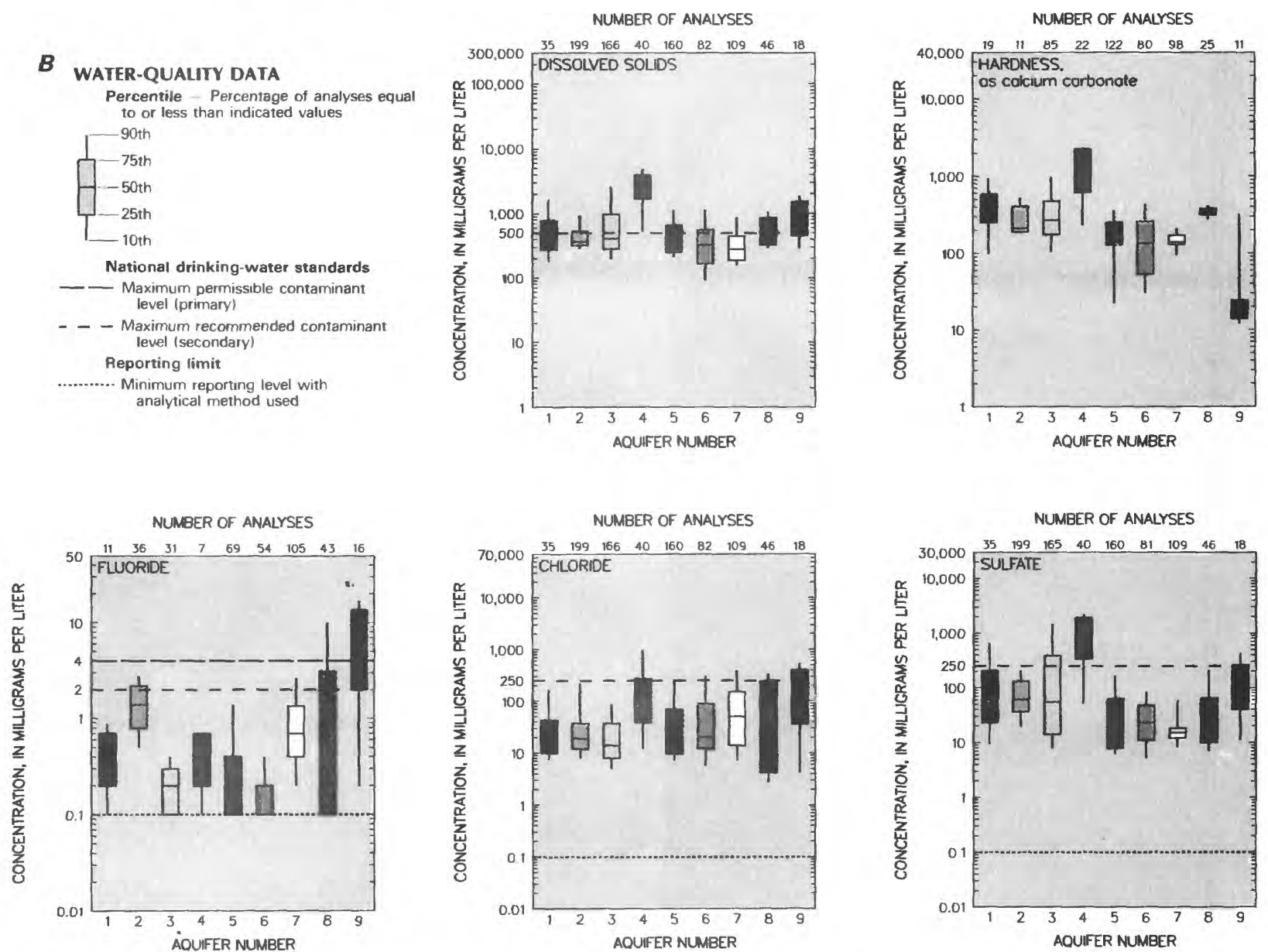

Figure 2. Principal aquifers and related water-quality data in Oklahoma. $A$, Principal aquifers. $B$, Selected water-quality constituents and properties, as of 1946-86. (Sources: A, Marcher, 1972. B. Analyses compiled from U.S. Geological Survey files; national drinking-water standards from U.S. Environmental Protection Agency, 1986 a,b.) 
WASTE SITE - Darker symbol indicates site where contaminants were detected in ground water. Numeral indicates more than one site at

same general location

- cercla (Superfund)

- r RCRA

- 3IRP

-. Waste-disposa! well (Underground Injection Control, class :

A

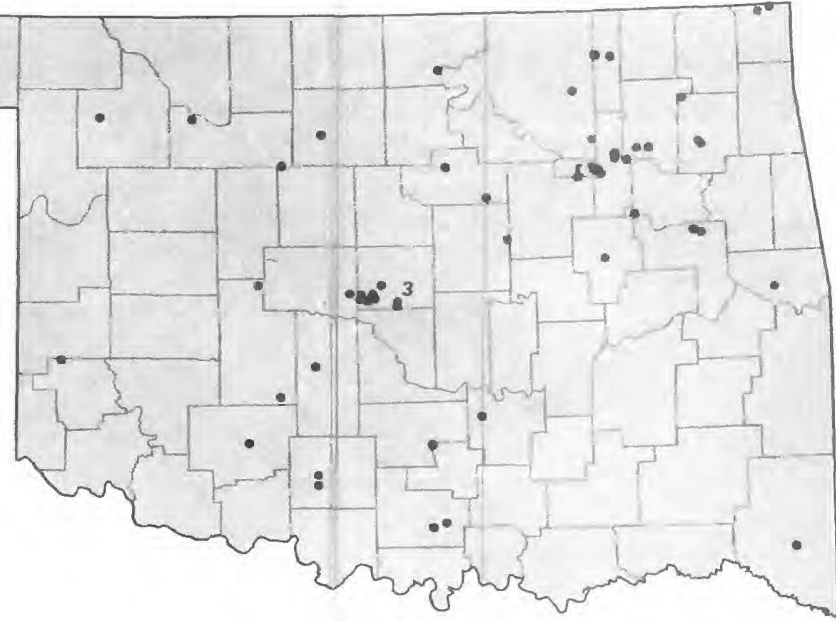

\section{GROUND-WATER QUALITY}

Area of water-quality concern

VZ Naturally impaired water quality

Human-induced contamination

-Well that yields contaminated water

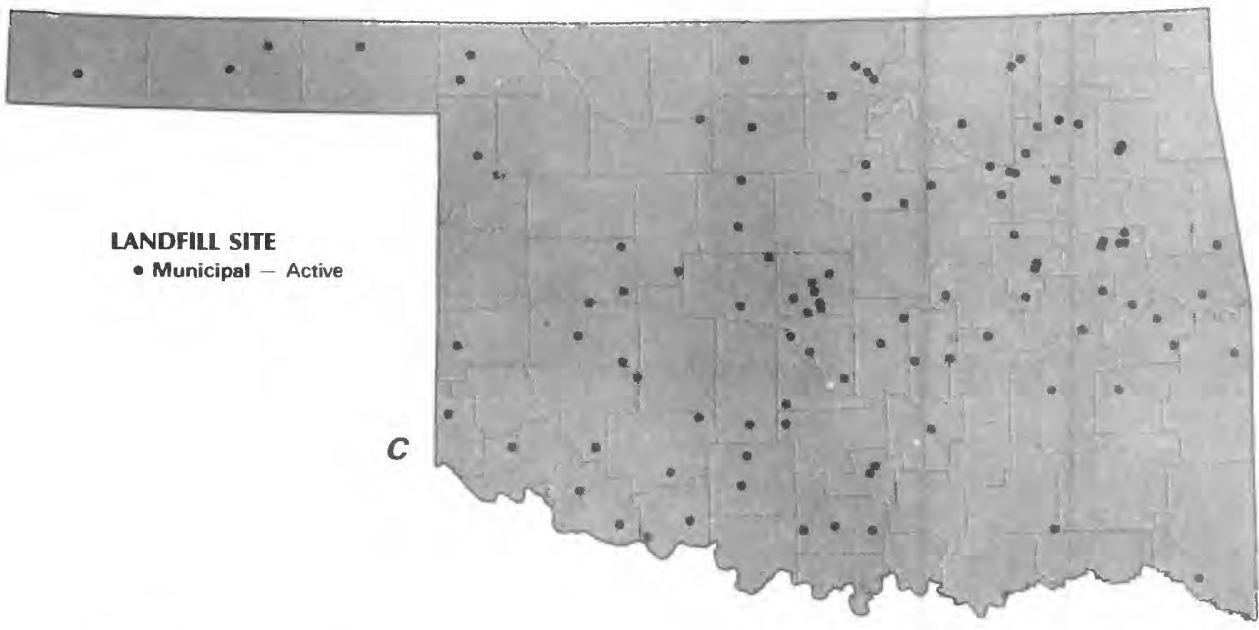

Figure 3. Selected waste sites and ground-water-quality information in Oklahoma. A, Comprehensive Environmental Response, Compensation, and Liability Act (CERCLA) sites, as of August 1986; Resource Conservation and Recovery Act (RCRA) sites, as of August 1986; and Department of Defense Installation Restoration Program (IRP) sites, as of September 1985; and other selected waste sites, as of August 1986. B. Areas of naturally-impaired water quality, areas of human-induced contamination, and distribution of wells that yield contaminated water, as of August 1986. C, Municipal landfills, as of August 1986. ISources: A, Oklahoma State Department of Health files; U.S. Department of Defense, 1986. B, U.S. Geological Survey, Oklahoma Water Resources Board, and Oklahoma State Department of Health files. C. Oklahoma State Department of Health files. I 
CHLORIDE PLUS SULFATE, IN PERCENT

OF TOTAL MILLIEQUIVALENTS PER LITER

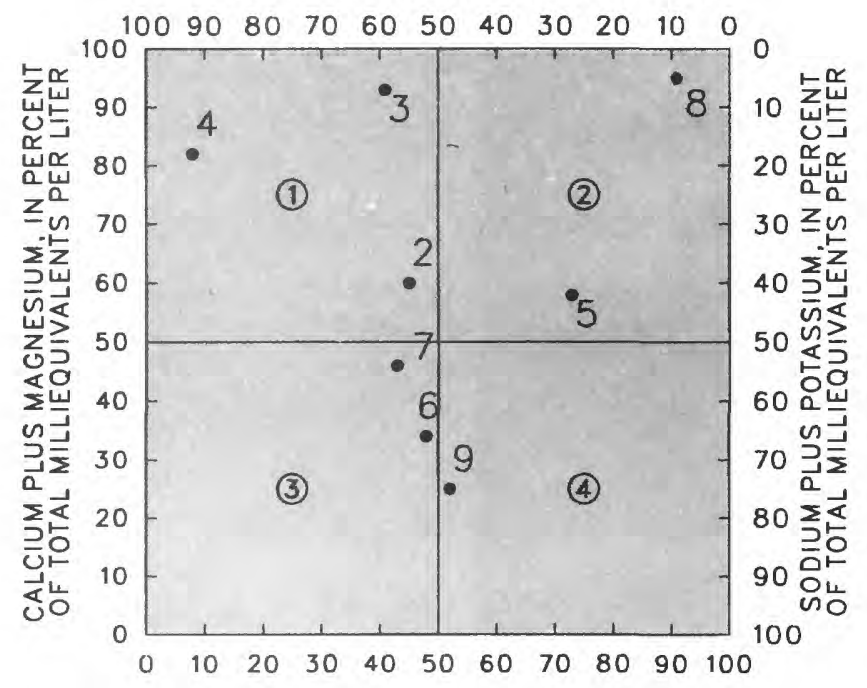

CARBONATE PLUS BICARBONATE. IN PERCENT OF TOTAL MILLIEQUIVALENTS PER LITER

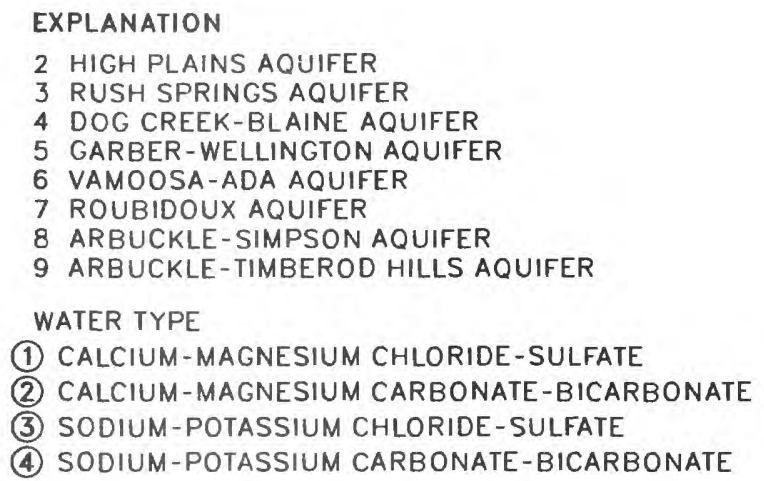

Figure 4. Water types of the principal aquifers in Oklahoma. Percentages are based on the average concentration of constituents. (Source: U.S. Geological Survey files.) 